\title{
Özel sektörün peyzaj mimarlığı lisans eğitiminden ve mezunlarından beklentileri
}

\author{
Işıl Kaymaz ${ }^{\mathrm{a}, *}$, Ecem Hoşgör ${ }^{\mathrm{a}}$
}

\begin{abstract}
Özet: $\mathrm{Bu}$ çalışmada peyzaj mimarlı̆̆ firmaların yeni mezunlardan ve buna bağlı olarak lisans eğitiminden beklentileri incelenmiştir. Çalışma kapsamında, peyzaj mimarlığı alanında farklı konularda faaliyet gösteren 77 özel sektör firmasına web tabanlı bir anket uygulanmıştır. Anket dokümanı firma profili, eğitim yeterliliği algısı ve sektörün mezunlardan ve eğitimden beklentileri olmak üzere üç başlık altında yapılandırılmıştır. Verilen yanıtlar IBM SPSS Statistics Base 22.0 programında frekans analizi, güvenilirlik analizi, faktör analizi ki-kare analizi ve sıralı regresyon analizleri aracılığıyla incelenmiştir. Açık uçlu soruda ise içerik analizi gerçekleştirilmiştir. Çalışmanın en belirgin sonucu özel sektörün genel olarak verilen lisans eğitimini, özellikle uygulama açısından, yeterli bulmayışıdır. Ayrıca, eğitimde kazanılan bilgi ve becerilerin, farklı faaliyet alanlarına göre farklı önemlere sahip olduğu sonucuna varılmıştır. Buna karşılık eğitim sektörü açısından en temel sorunlardan bir tanesi öğrenci sayısının her yıl artması; buna bağlı olarak üniversitelerde gerek personel gerekse fiziksel mekân koșullarının talebi karșılayamıyor olmasıdır. Bununla birlikte peyzaj mimarlığı çalışma alanlarının çeşitlilik göstermesi de eğitimin kalitesini zorlayıcı unsurlardan bir diğeridir. Ancak, meslek disiplininin sorunlarına ilișkin çözümlerin geliștirilmesinde her iki paydaşın da aynı sorumluluğa sahip olduğu ve ortak hareket etmenin peyzaj mimarlığı disiplinini güçlendireceği unutulmamalıdır. Anahtar kelimeler: Peyzaj mimarlığı, Peyzaj mimarlığı eğitimi, Özel sektör
\end{abstract}

\section{Private sector's expectations on landscape architecture undergraduate education and newly graduates}

\begin{abstract}
This study investigates the private sector's expectations on landscape architecture undergraduate education and newly graduates in Turkey. Data was gathered through a web-based questionnaire survey, answered by 77 private sector firms in the field of landscape architecture. The questionnaire survey consisted of three parts; firm profile, sufficiency of the education and the private sector's expectations from the graduates and undergraduate education. Responses were analysed through frequency analysis, reliability analysis, factor analysis, chi square test and ordinal regression analysis using IBM SPSS Statistics Base 22.0 software. Content analysis was conducted to evaluate open-ended questions. The most outstanding outcome of the research is that undergraduate education, particularly practice component was found to be insufficient by the private sector. Moreover, evaluation of the acquired knowledge and abilities on different fields of landscape architecture differed for the firms which were specialized in different fields of landscape architecture. On the other hand, one of the basic problems for the education sector is the increasing number of students enrolled in landscape architecture programs and the insufficiency of both academic staff and the physical conditions required. Besides, the peculiar and diverse character of the different practice fields in landscape architecture also limits the quality of education. However, it should be noted that as stakeholders of landscape architecture discipline, both education and private sectors should work in co-operation with each other in order to overcome the problems faced and to enforce the discipline.
\end{abstract}

Keywords: Landscape architecture, Landscape architecture education, Private sector

\section{Giris}

Peyzaj mimarlığı disiplini farklı ölçeklerde peyzajı biçimlendirmeye yönelik olarak; peyzajların çok yönlü doğasını ve insanla etkileşimi inceleyen bir disiplindir (Bruns vd., 2010; Fetzer, 2014). Bu nedenle peyzaj mimarlığ disiplini eş zamanlı olarak doğal bilimler ve sanatsal yaratıcılık alanlarında geniş erimli bilginin farkındalığını gerektiren alışılmamış bir karaktere sahiptir (Gazvoda, 2002). Bununla birlikte günümüz karmaşık çevre ve sosyal sorunlarına dar kapsamlı ve tek odaklı çözümler yetersiz kaldığından, peyzaj mimarlığı disiplini de çok amaçlı (ekolojik, sosyo-ekonomik, politik vb.) yaklaşımlara doğru bir yönelim göstermektedir (Kaplan, 2009). Bu nedenle çalışma alanları da interdisipliner ve çoğu zaman da karmaşı süreçleri içerir.

Ülkemizde ilk defa Yüksek Ziraat Enstitüsü bünyesinde verilen "Bahçe Mimarisi Sanatı" ve "Bahçe Mimarisi Tarihi” dersleri ile adım alan peyzaj mimarlığı öğretimi, 1968 y1lında Ankara Üniversitesi Ziraat Fakültesi'nde kurulan Türkiye'nin ilk peyzaj mimarlığı bölümü ile eğitim sürecine resmen başlatmıştır. $\mathrm{Bu}$ doğrultuda peyzaj mimarlığı eğitimi veren bölümler ilk olarak Ziraat ve Orman Fakülteleri altında yapılanmıştır. Bugün ise peyzaj

\footnotetext{
$\square$ a Ankara Üniversitesi Ziraat Fakültesi Peyzaj Mimarlığı Bölümü, Dışkapı, Ankara

@ * Corresponding author (İletişism yazarı): cakci@ agri.ankara.edu.tr

$\checkmark \quad$ Received (Geliş tarihi): 29.11.2018, Accepted (Kabul tarihi): 14.12.2018
}

Citation (Atıf): Kaymaz, I., Hoşgör, E., 2018. Özel sektörün peyzaj mimarlığı lisans eğitiminden ve mezunlarından beklentileri. Turkish Journal of Forestry, 19(4): 403-412. DOI: $\underline{10.18182 / \mathrm{tjf} .489812}$ 
mimarlığı lisans eğitimi Türkiye'de "Mimarlık", "Ziraat", "Orman", "Güzel Sanatlar ve Tasarım" gibi çok farklı fakülteler altında verilmektedir. Buna ek olarak bölüm adları da bazı üniversitelerde farklılık göstermekte; "Kentsel Tasarım ve Peyzaj Mimarisi/Mimarlı̆̆ı” ismi altında peyzaj mimarlığı eğitimi veren programlar da bulunmaktadır (Çizelge 1). Ancak her iki bölümden mezun olanlar da 'peyzaj mimarı' ünvanı almaktadır.

Öğrenci Seçme ve Yerleştirme Merkezi (ÖSYM) verilerine göre 2017 'de lisans öğrencisi alan peyzaj mimarlı̆̆ bölümü sayısı 32 iken, bu sayı 2018'de 40'a yükselmiştir. Çizelge 1'de 2017 ve 2018 yıllarında peyzaj mimarlığı bölümlerine yerleştirilen öğrenci sayıları (ek kontenjanlar dahil) ile birlikte eğitim veren üniversiteler ve programların bağlı olduğu fakülteler görülmektedir. Buna göre peyzaj mimarlığı lisans programlarının \%30'u Mimarlık Fakülteleri kapsamında, \%27'si ise Ziraat ve Orman Fakülteleri altında yapılanmaktadır (Çizelge 2).
2018 yılında Türkiye de peyzaj mimarlığı eğitimi 50 . yılını doldurmuştur. $\mathrm{Bu}$ süreç içerisinde hem ulusal hem uluslararası ölçekte peyzaj mimarlığının ne olduğu ve kapsamı tartışmaya açıklığını koruduğu gibi, eğitim de kaçınılmaz olarak bu tartışmanın önemli bir ayağını oluşturmaktadır. Peyzaj mimarlığının içsel karmaşasına ek olarak; eğitimin Türkiye'deki yapılanması da bölümler arası farklılık göstermektedir. Örneğin İstanbul Teknik Üniversitesi (İTÜ) Mimarlık Fakültesi Peyzaj Mimarlığı Bölümü'nde uygulamalı tasarım derslerinin toplam ulusal kredi içindeki payı \%46 iken; İstanbul Üniversitesi (ïÜ) Orman Fakültesi Peyzaj Mimarlığı Bölümü'nde \%43, Ankara Üniversitesi (AÜ) Ziraat Fakültesi Peyzaj Mimarlığı Bölümü'nde ise \%22'dir (Şekil 1). Ankara Üniversitesi’nde ise mühendislik içerikli derslerin diğer iki bölüme oranla daha fazla paya sahip olduğu görülmektedir.

Çizelge 1. 2017 ve 2018 yıllarında üniversitelerin peyzaj mimarlığı bölümlerine yerleşen öğrenci sayıları (ÖSYM, 2017; ÖSYM, 2018a; ÖSYM, 2018b)

\begin{tabular}{|c|c|c|c|}
\hline Üniversite adı & Fakülte adı & $\begin{array}{l}\text { Yerleşen öğrenci } \\
\text { sayı1s1 - } 2017\end{array}$ & $\begin{array}{l}\text { Yerleşen öğrenci } \\
\text { sayı1 - } 2018\end{array}$ \\
\hline \multicolumn{4}{|l|}{ Peyzaj Mimarlığı Bölümü } \\
\hline Adnan Menderes Üniversitesi & Ziraat Fakültesi & 52 & 68 \\
\hline Akdeniz Üniversitesi & Mimarlık Fakültesi & 47 & 62 \\
\hline Ankara Üniversitesi & Ziraat Fakültesi & 68 & 78 \\
\hline Artvin Çoruh Üniversitesi & Sanat ve Tasarım Fakültesi & 16 & 20 \\
\hline Atatürk Üniversitesi & Mimarlık ve Tasarım Fakültesi & 62 & 67 \\
\hline Bartın Üniversitesi & Orman Fakültesi & 31 & 23 \\
\hline Bursa Teknik Üniversitesi & Orman Fakültesi & - & 24 \\
\hline Çanakkale Onsekiz Mart Üniversitesi & Mimarlık ve Tasarım Fakültesi & 62 & 65 \\
\hline Çankırı Karatekin Üniversitesi & Orman Fakültesi & 26 & 8 \\
\hline Çukurova Üniversitesi & Mimarlık Fakültesi & 62 & 67 \\
\hline Düzce Üniversitesi & Orman Fakültesi & 62 & 42 \\
\hline Ege Üniversitesi & Ziraat Fakültesi & 65 & 69 \\
\hline Lefke Avrupa Üniversitesi & Mimarlık Fakültesi & 0 & 1 \\
\hline Iğdır Üniversitesi & Ziraat Fakültesi & - & 3 \\
\hline İnönü Üniversitesi & Güzel Sanatlar ve Tasarım Fakültesi & 57 & 46 \\
\hline İskenderun Teknik Üniversitesi & Mimarlık Fakültesi & - & 12 \\
\hline İstanbul Teknik Üniversitesi & Mimarlık Fakültesi & 50 & 66 \\
\hline İstanbul Üniversitesi & Orman Fakültesi & 77 & 72 \\
\hline İzmir Demokrasi Üniversitesi & Mimarlık Fakültesi & - & 66 \\
\hline Kahramanmaraş Sütçü İmam Üniversitesi & Orman Fakültesi & 30 & 25 \\
\hline Karadeniz Teknik Üniversitesi & Orman Fakültesi & 62 & 63 \\
\hline Kastamonu Üniversitesi & Mühendislik ve Mimarlık Fakültesi & 52 & 30 \\
\hline Mehmet Akif Ersoy Üniversitesi & Mühendislik ve Mimarlık Fakültesi & 36 & 38 \\
\hline Mustafa Kemal Üniversitesi & Mimarlık Fakültesi & 30 & 28 \\
\hline Namık Kemal Üniversitesi & Güzel Sanatlar, Tasarım ve Mimarlık Fakültesi & 52 & 68 \\
\hline Nevşehir Hacı Bektaş Veli Üniversitesi & Mühendislik ve Mimarlık Fakültesi & 41 & 26 \\
\hline Ordu Üniversitesi & Ziraat Fakültesi & 31 & 32 \\
\hline Pamukkale Üniversitesi & Mimarlık ve Tasarım Fakültesi & - & 64 \\
\hline Recep Tayyip Erdoğan Üniversitesi & Güzel Sanatlar, Tasarım ve Mimarlık Fakültesi & 36 & 27 \\
\hline Selçuk Üniversitesi & Ziraat Fakültesi & 52 & 67 \\
\hline Siirt Üniversitesi & Ziraat Fakültesi & - & 5 \\
\hline Süleyman Demirel Üniversitesi & Mimarlık Fakültesi & 52 & 66 \\
\hline Trakya Üniversitesi & Mimarlık Fakültesi & 62 & 62 \\
\hline Uludağ Üniversitesi & Ziraat Fakültesi & - & 22 \\
\hline Van 100. Y1l Üniversitesi & Mimarlık ve Tasarım Fakültesi & - & 18 \\
\hline Yakın Doğu Üniversitesi (KKTC) & Mimarlık Fakültesi & 3 & 1 \\
\hline \multicolumn{4}{|c|}{ Kentsel Tasarım ve Peyzaj Mimarlığı/Mimarisi Bölümü } \\
\hline Amasya Üniversitesi & Mimarlık Fakültesi & 42 & 36 \\
\hline Bilkent Üniversitesi & Güzel sanatlar, Tasarım ve Mimarlık Fakültesi & 30 & 40 \\
\hline Yeditepe Üniversitesi & Mimarlık Fakültesi & 7 & 8 \\
\hline \multirow[t]{2}{*}{ İstanbul Medipol Üniversitesi } & Güzel sanatlar, Tasarım ve Mimarlık Fakültesi & 13 & 12 \\
\hline & Toplam: & 1368 & 1597 \\
\hline
\end{tabular}


Çizelge 2. 2018 yılı lisans öğrencisi alan peyzaj mimarlığı programlarının bağlı oldukları fakültelere göre dağılımı

\begin{tabular}{lrr}
\hline Fakülte adı & Bölüm sayısı & Yüzde (\%) \\
\hline Ziraat Fakültesi & 20 \\
Mimarlık Fakültesi & 30 \\
Mimarlık ve Tasarım Fakültesi & 3 & 3,5 \\
Sanat ve Tasarım Fakültesi & 2,5 \\
Mühendislik ve Mimarlık Fakültesi & 1 & 10 \\
Güzel Sanatlar ve Tasarım Fakültesi & 4 & 1 \\
Güzel Sanatlar, Tasarım ve Mimarlık Fakültesi & 4,5 \\
Orman Fakültesi & 10 \\
\hline
\end{tabular}

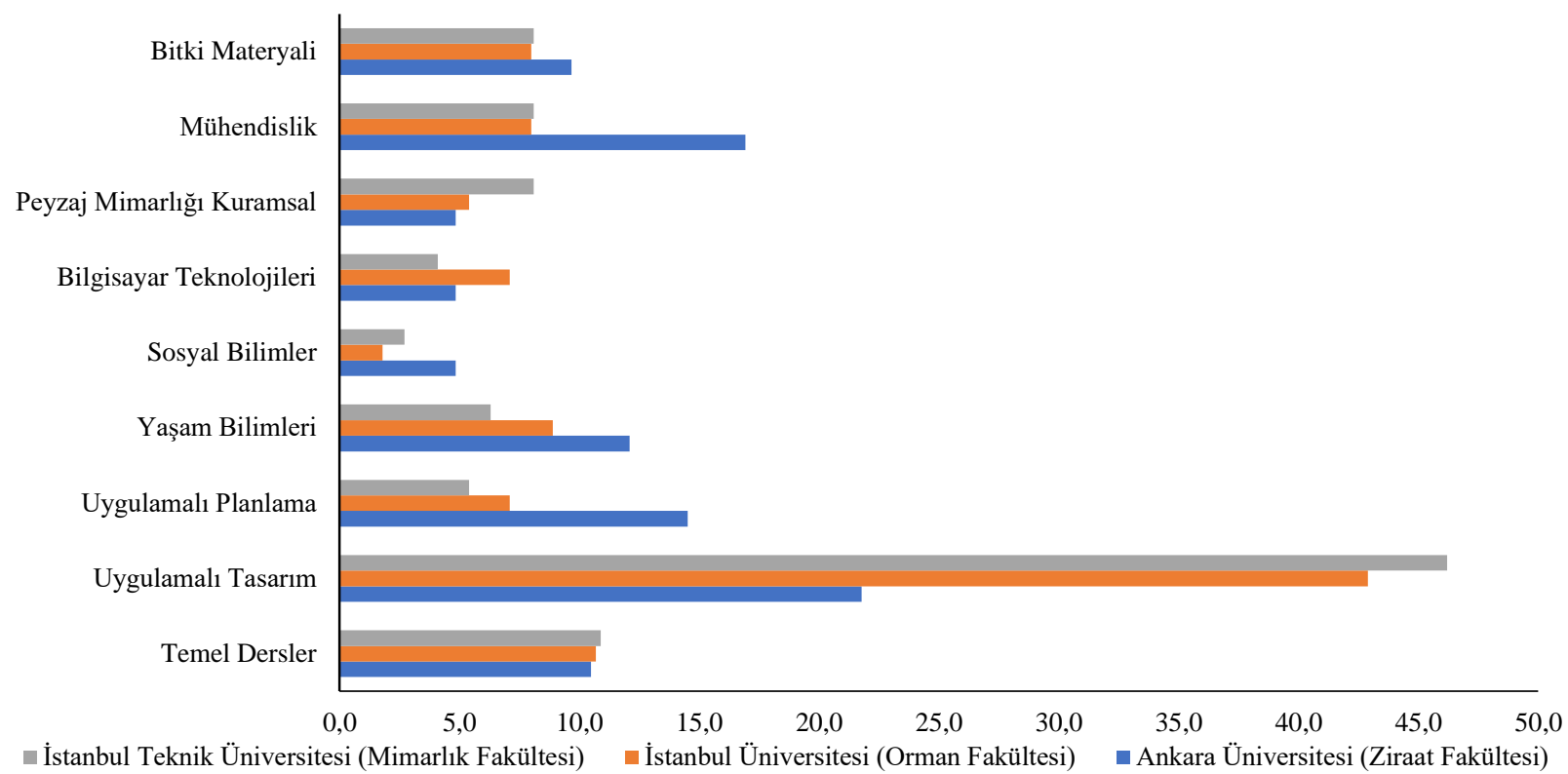

Şekil 1. Farklı fakültelere bağlı peyzaj mimarlığı lisans programlarında derslerin konulara göre dağılımı (\%:Dağılım belirlenirken ulusal krediler ve zorunlu dersler temel alınmıştır; seçmeli dersler ve yabancı dil dersleri göz ardı edilmiştir. Temel Dersler ise Yükseköğretim Kurulu tarafından tüm bölümler için okutulması zorunlu olan Fizik, Kimya, Türk Dili vb. dersleri kapsamaktadır.) (Anonim, 2018a; Anonim, 2018b; Anonim, 2018c)

Buna ek olarak eğitimdeki kalitenin bir göstergesi olan akreditasyon süreci de yükseköğretim programlarının eğitim boyutunu yakından ilgilendirmektedir. Ülkemizde henüz ulusal olarak peyzaj mimarlığg bölümlerini akredite eden bir kurum ya da kuruluş bulunmamaktadır. Ancak İTÜ Mimarlık Fakültesi Peyzaj Mimarlı̆̆ı Bölümü, 2017'de Uluslararası Peyzaj Mimarlığı Federasyonu (IFLA) tarafindan 2017'de tam akredite edilmiştir (Anonim, 2017). IFLA/UNESCO Peyzaj Mimarlığı Eğitimi Belgesi (2012)'ne göre peyzaj mimarlı̆̆1; mimari, sanatsal, ekolojik, mühendislik ve bilimsel ilkeleri bütünleştirir ve dolayısıyla peyzaj mimarlığı eğitimi de kavramlaştırma, koordine etme ve insan gelenekleri ile doğal ve kültürel sistemleri temel alan tamamlayıcı tasarımları gerçekleştirme kapasitesini desteklemelidir.

Yukarıda verilen güncel durum doğrultusunda, farklı üniversitelerin peyzaj mimarlığı bölümlerinden mezunların peyzaj mimarlığı alanında bilgi ve becerileri ile bunların peyzaj mimarlığı pratiği içindeki yeri de sorgulamaya açık hale gelmektedir. Özellikle artan öğrenci ve buna bağlı mezun sayıları gerek eğitim gerekse sektörel istihdam açısından kaygı vericidir. Tüm bu karmaşık yapı içinde peyzaj mimarlı̆̆ arasındaki ilişkinin sorgulanması gerekmektedir. TMMOB Peyzaj Mimarları Odası (PMO)'ndan elde edilen ve yazılı olmayan verilere göre; toplam üye sayısı 2018 yılı ilk yarısında 5881 kişi olup; ilk kayıt verilerine göre 1357'si (\%23) özel sektörde, 1629’u (\%28) kamu sektöründe istihdam edilmektedir. $\mathrm{Bu}$ saylar güncel olmamakla birlikte, her mezunun meslek odasına kaydı da söz konusu değildir. Buna ek olarak peyzaj mimarlarının kamuda istihdamında kadro ünvanı ve kadro sayısı konusunda farklı sorunlar da bulunmaktadır. Örneğin, Yükseköğretim Kurulu Başkanlığı (YÖK), 2107 yılında aldığı bir kararla mezunlarının mimarlık eğitimine eşdeğer bir eğitim almadıkları gerekçesiyle, peyzaj mimarlarının ve iç mimarların kamu kurum ve kuruluşlarında "mimar" kadrosuna atanmalarının uygun olmadı̆̆ını belirtmiştir (PMO, 2018). Dolayısıyla peyzaj mimarlığı disiplini ve buna bağlı olarak eğitimi ulusal ölçekte farklı sorunlara yönelik mücadele eylemleri ve çözümleri üretmek durumundadır. Peyzaj mimarlığı eğitim sektörü de bu arayışın kaçınılmaz bir parçasıdır.

Gül vd. (2011)'nin de belirttiği üzere peyzaj mimarlığı eğitim ve öğretim ihtiyaçlarının belirlenebilmesi için günümüz şartlarının ve mevcut paydaşların talep ve eğilimlerinin değerlendirilmesi gerekmektedir. $\mathrm{Bu}$ çalışmada da peyzaj mimarlığı özel sektörü hedef paydaş olarak belirlenmiştir. Her ne kadar Peyzaj Mimarlığı Bölüm Başkanları Konseyi (PEMKON) tarafından ilki 2014'te 
Antalya'da, ikincisi ise 2018'de Düzce'de gerçekleştirilen "Peyzaj Mimarlığı Eğitim-Öğretim” çalıştayları kapsamında peyzaj mimarlığı eğitiminin farklı boyutları tartışılmış olsa da ulusal literatürde özel sektörün peyzaj mimarlığı mezunlarından beklentilerine yönelik ayrıntılı bir bilimsel çalışma bulunmamaktadır.

$\mathrm{Bu}$ çalışma; peyzaj mimarlığı mezunlarının önemli bir kısmının istihdam edildiği özel sektörde faaliyet gösteren firmaların yeni mezunlardan ve buna bağlı olarak lisans eğitiminden beklentilerini irdelemektedir. Çalışma sonucunda özel sektörün bilgi ve beceri konusunda mezunlardan beklentileri ve eleştirileri doğrultusunda peyzaj mimarlığı lisans programları üzerinde eleştirel bir irdeleme yapılmıştır. Ulusal ve uluslararası eğitim hedeflerinin ortaya konmasında paydaşların görüşlerinin de dikkate alınması gerekliliğinden yola çıkarak, çalışma sonuçlarının peyzaj mimarlığı eğitim programlarının yeniden yapılanmasına katkıda bulunması beklenmektedir.

\section{Materyal ve yöntem}

Bu çalışmada peyzaj mimarlığı alanında farklı konularda faaliyet gösteren özel sektör firmalarının yeni mezunlardan beklentileri, IFLA akreditasyon belgesi kapsamında ifade edilen peyzaj mimarlığı eğitim programlarında hedeflenmesi gereken bilgi ve beceriler temel alınarak irdelenmiştir. Bu bilgi ve beceriler aşağıdaki gibidir (IFLA, 2012):

- Kültürel formun tarihi ve tasarımın bir sosyal sanat olarak idrak edilmesi,

- Sosyal, politik, ekonomik ve doğal sistemler,

- Jeoloji, biyoloji vb. doğa bilimleri,

- Bitki materyali ve bitki üretimi uygulamaları,

- Arazi mühendisliği,

- Tasarım, planlama ve araştırma kuramı ve yöntemleri,

- Peyzaj tasarımı, yönetimi, planlaması ve bilimi (tüm ölçeklerde),

- Ekolojik çalışmalar ve sürdürülebilirlik ilkeleri,

- Bilgi teknolojisi ve bilgisayar uygulamaları,

- Kamu politikaları,

- İletişim,

- Etik değerler.

$\mathrm{Bu}$ amaçla özel sektörde faaliyet gösteren firmalarla internet üzerinden bir anket çalışması gerçekleştirilmiştir. Peyzaj mimarlığı sektörünün önde gelen temsilcilerine ulaşmak amacıyla 2018 yılında TMMOB PMO'ndan büro tescil belgesi alan firmaların ve Süs Bitkileri Üreticileri Alt Birliği 2018 yılı üye listesinden, özellikle bitkisel üretim ve uygulama alanında, ilgili meslek odasına kayıtlı olmayan firmaların e-posta adreslerine, web tabanlı hazırlanan ankete davet gönderilmiştir. Şubat-Mart 2018 tarihleri arasında elektronik ortamda gerçekleştirilen anket çalışmasına, davet gönderilen 760 firmadan 77 tanesi (\%10) yanıt vermiştir.

Anket dökümanı; firma profili, eğitim yeterliliği ve sektör beklentileri olmak üzere üç başlık altında yapılandırılmıştır. Toplam 16 soru içeren ankette; likert tipi, çoktan seçmeli ve açık uçlu sorulara yer verilmiştir. Verilen yanitlar IBM SPSS Statistics Base 22.0 programında frekans analizi, güvenilirlik analizi, faktör analizi, ki-kare analizi ve regresyon analizleri aracılığıyla incelenmiştir. Açık uçlu soruda ise içerik analizi gerçekleştirilmiştir.
Likert tipi ve çoktan seçmeli soruların güvenirlik testinde Cronbach alfa katsayısı kullanılmış ve 0.913 değerinde yüksek güvenilirlik düzeyinde saptanmıştır. Güvenilir bulunan verilerin faktör analizi için uygunluğu Kaiser-Meyer-Olkin (KMO) katsayısı ile incelenmiştir. Tüm veriler için KMO katsayısı 0.5 'ten büyük olarak saptanmış ve faktör analizi için geçerli kabul edilmiştir. Faktör analizinde dik (varimax) rotasyon kullanılmış ve öz değeri (eigenvalue) 1'in üzerinde olan faktörler anlamlı olarak kabul edilmiştir.

Farklı sorular ile elde edilen veriler arasındaki ilişkilerin anlamlılı̆̆ının belirlenmesinde ilk aşamada ki-kare testi (Pearson's Chi-square Test) uygulanmış ve $\% 95$ güven aralığı kullanılmıştır. Ancak ki-kare testi değişkenler arası ilişskinin gücü ve yönü konusunda bilgi sağlamamaktadır. $\mathrm{Bu}$ nedenle değişkenler arası ilişkinin daha ayrıntılı irdelenmesi amacıyla, bağımlı değişkenler sıralı (ordinal) veri karakterinde olduğu için, sıralı regresyon analizi kullanılmıştır. Sıralı regresyon analizinin sonuçlarının değerlendirilmesinde ilk olarak paralellik varsayımı ve modelin uyum iyiliği test edilmiştir. Gerek paralellik varsayımı gerekse uyum iyiliği olasılıkları (p) 0.05 'ten büyük olan veriler modelle uyumlu olarak kabul edilmiş ve değerlendirmeye alınmıştır. İlişkilerin yorumlanmasında parametre değerlerinin hesaplanan "odds oranı" ("e üssü" değerleri) (OR) kullanılmıştır. Sıralı regresyon analizinin yorumlanmasında bağımsız değişkene ilişkin OR değerlendirmeye alındığı için, bağımlı değişkene ait parametre değerleri ilgili Çizelgelerde belirtilmemiştir.

Açık uçlu sorunun değerlendirilmesinde kullanılan içerik analizi kapsamında katılımcılar tarafından yazılan metinlerin her biri ele alınarak, katılımcıların vurgu yaptıkları kavramlar belirlenmiştir. Bir sonraki aşamada bu kavramların farklı katılımcılar tarafından ne kadar sıklıkla tekrar edildiği incelenerek sınıflandırılmıştır.

\section{Bulgular}

$\mathrm{Bu}$ bölümde anketlerden elde edilen verilere ilişkin değerlendirmeler, anket formunda olduğu gibi üç temel başlık altında irdelenmiştir.

\subsection{Firma profili}

Anketin firma profilini belirlemeye yönelik hazırlanmış bu bölümünde; firmaların faaliyet alanlarına, faaliyet sürelerine ve personel sayılarına ilişkin sorular yer almıştır. Bulgulara göre ankete yanıt veren firmalar arasında en fazla pay $(\% 20)$ hem tasarım hem uygulama hem de bitkisel üretim alanında faaliyet gösterenlere ait iken, yalnızca planlama alanında faaliyet gösteren firma bulunmamaktadır (Şekil 2). Firmaların büyük çoğunluğu (\%69) birden fazla faaliyet alanına sahiptir. $\mathrm{Bu}$ faaliyet alanları içerisinde bitkisel üretim ve bitki satışı ile uygulama (müteahhitlik hizmetleri) alanları öne çıkmaktadır. Firmaların \%52'si 15 yıldan uzun süredir alanlarında faaliyet göstermektedir. Firmaların istihdam ettiği peyzaj mimarı sayısı ise 0-10 arasında değişkenlik göstermektedir. Firmaların \%27'si 1; \%22'si 2; \%14'ü 3 ve \%23'ü 3'ten fazla peyzaj mimarlığ lisans programı mezunu eleman istihdam ederken $\% 14$ oranında firmada peyzaj mimarlığ 1 lisans programı mezunu bulunmamaktadır. 


\section{2. Ĕ̈itim yeterliliği}

Katılımcı firmaların istihdam ettikleri peyzaj mimarlarından bekledikleri niteliklerden en öncelikli olanlar sırasıla; (i) koordinasyon ve planlama becerisi, (ii) tasarım ve yaratıcılık yeteneği ve (iii) teknik program bilgisidir (Şekil 3). İş geliştirme ve inisiyatif kullanabilme becerileri de en az uygulama konusunda deneyim kadar önemli bulunmaktadır. Bununla birlikte firmaların \%39'u üniversiteler tarafından verilen eğitimin sektörün beklentilerini karşılama konusunda yetersiz; \%25'i ise kısmen yeterli olduğunu belirtmiştir.

Firmaların faaliyet alanı ve istihdam edilen peyzaj mimarlarından beklenen niteliklerin öncelikleri hakkındaki değerlendirmeleri arasında anlamlı bir ilişki olup olmadığının anlaşılması için öncelikle ki-kare testi uygulanmıştır. Ancak ki-kare testi sonucunda değişkenler arasında anlamlı bir ilişki saptanamamıştır $(\mathrm{p}=0.57)$. Ki-kare testi sonucuna rağmen siralı regresyon analizi gerçekleştirilmiş; bu analiz sonucunda mezunların şantiye deneyimi ile firma faaliyet alanı arasında anlamlı bir ilişki bulunmuştur (Çizelge 3). $\mathrm{Bu}$ analiz sürecinde, firma profilinde ortaya konan 10 farklı faaliyet alanı yeniden sınıflandırılmış ve (i) yalnızca bitkisel üretim ve uygulama yapan firmalar, (ii) yalnızca tasarım ve planlama konularında proje hizmeti veren firmalar ve (iii) iki ve/veya daha çok alanda hem proje hem uygulama hizmeti veren firmalar olmak üzere 3 kategoriye indirgenmiştir. Sıralı regresyon analizi için referans kategori, belirli bir uzmanlık alanına/bilgiye/beceriye yönelen yanıtların olasılığı diğer gruplara oranla daha düşük olduğu için, çoklu faaliyet alanına sahip firma tipleri olarak belirlenmiştir. Çizelge 3 'te tasarım ve planlama alanlarında yalnızca proje hizmeti sunan firmaların, mezunlardan şantiye deneyimi konusunda düşük beklentiye sahip olma olasılıkları, çoklu faaliyet alanına sahip firmalara göre 4 kat daha fazla olduğu görülmektedir. $\mathrm{Bu}$ beklenen bir sonuç olmakla birlikte Türkiye genelinde yalnızca proje hizmeti veren firmaların, oransal olarak, daha az sayıda olmalarından dolayı uygulamaya ilişkin deneyim, aranan bir nitelik olmaya devam edecektir. Nitekim firmaların büyük bir kısmı (\%79) işe aldıkları yeni mezun peyzaj mimarları için alıştırma sürecine ihtiyaç duyduklarını belirtmişlerdir. $\mathrm{Bu}$ durumun yeni mezunların, işveren tarafından meslek pratiğinde yetersiz bulunmaları olarak yorumlanabilir.

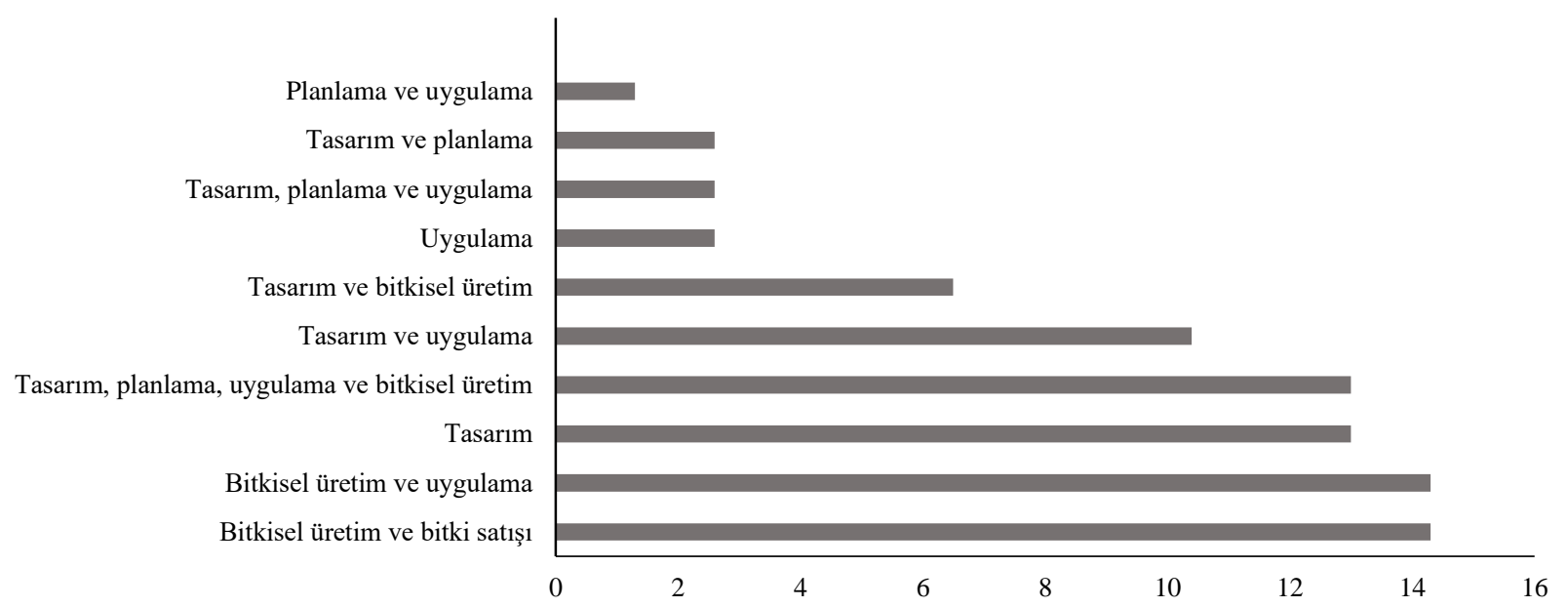

Şekil 2. Ankete katılan firmaların faaliyet alanlarının dağılımları (\%)

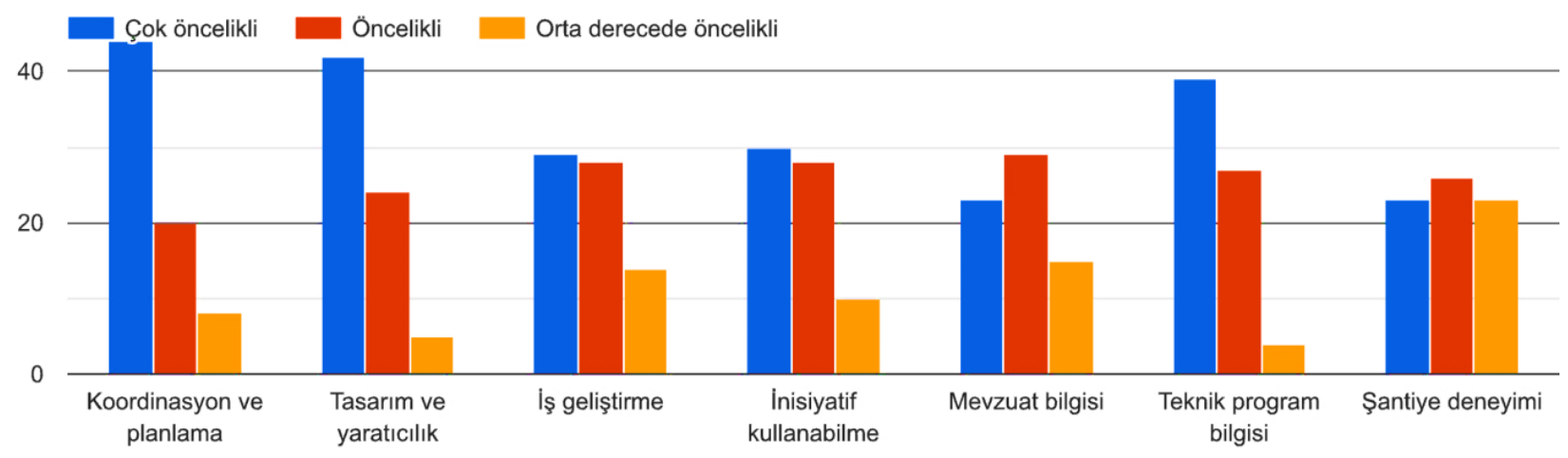

Şekil 3. Katılımcı firmaların peyzaj mimarlarından bekledikleri niteliklerin öncelik sıralaması

Çizelge 3. Firma faaliyet alanına göre mezunlardan şantiye deneyimi beklentileri

\begin{tabular}{lcccc}
\hline Bağımlı değişken: Şantiye deneyimi niteliğinin önceliği & $\beta$ & Wald & OR $\left(\mathrm{e}^{\beta}\right)$ & $\mathrm{p}$ \\
Bağımsız değişken: Firma faliyet alanı & -485 & 0.918 & & 0.338 \\
\hline Bitkisel üretim ve uygulama & 1.465 & 4.866 & 4.327543 & 0.027 \\
Tasarım ve Planlama & $0^{\mathrm{a}}$ &. &. &. \\
Çoklu faaliyet alanı & & &. \\
\hline
\end{tabular}


Peyzaj mimarlığ lisans eğitiminin, sektörel beklentileri karşılama konusunda, üniversitelere göre farklılık gösterdiğini ifade eden firma sayısı 17 (\%22) iken; 10 firma (\%13) eğitim niteliğinin faaliyet alanlarına göre (tasarım, planlama, uygulama vb.) farklılık gösterdiğini belirtmiştir. Buna karşılık bölümlerin bağlı bulundukları fakültenin, eğitimi etkilediğini belirten firma sayısı çoğunluktadır (\%75). Bununla birlikte eğitimde, programın ana bilim dallarına ayrılmasını gerekli gören katılımcı firma oranı \%52 iken, \%43'ü anabilim dalı yapılanmasını gerekli bulmamaktadır. Firmaların \%5'i ise kararsızdır. Halihazırda peyzaj mimarlığı lisans programlarının anabilim dallarına ilişkin yapılanması da üniversitelere göre farklılık göstermektedir. Ancak 2013 yılında gerçekleştirilen 7. PEMKON toplantısı 4 no'lu kararına göre "bölümlerden gelen görüşler doğrultusunda, yeni kurulacak ve yeniden yapılandırllacak Peyzaj Mimarlı̆̆ Bölümlerinde; "Peyzaj Planlama", "Peyzaj Tasarımı" ve "Bitki Materyali" başlıkları altında asgari üç anabilim dalının yer alması, fakülte yapıları ve akademik gelişmeler dikkate alınarak, ihtiyaç duyulacak yeni anabilim dallarının açılmasının uygun olacă̆ına" oybirliği ile karar verilmiştir (PEMKON, 2018). Bununla birlikte PEMKON'un gönüllülük esasına dayalı bir yapılanma olduğu ve ulusal eğitim programları üzerinde bir yaptırım gücü bulunmadığı da göz önüne alınmalıdır.

Katılımcı firmaların mevcut durumda lisans eğitimi ve yeni mezunların eğitim yeterliliklerine ilişkin görüşleri ise Çizelge 4'te verilmiştir. Çizelge 4'te yer alan ifadeler için gerçekleştirilen faktör analizi sonucunda, toplam varyansı açıklayan birbirinden bağımsız üç faktör tanımlanmıştır; (i) kişisel beceri ve gelişim, (ii) eğitim yeterliliği ve (iii) meslek pratiğine yönelik faaliyetler. Nitekim Çizelge 4'te verilen yüzde dağılımları incelendiğinde; (i) derslerin uygulama ağırlıklı yürütülmesi, (ii) staj sürelerinin daha uzun olması gerekliliği, (iii) kişisel gelişime yönelik girişimler, (iv) eğitimcilerin özel sektörle iletişim halinde olmaları ve (v) yeni mezunların güncel sektörel gelişmeler konusunda farkındalıklarının artırılması öne çıkmaktadır. $\mathrm{Bu}$ bulgulara dayanarak, özellikle eğitim sektörü ve özel sektör arasında bir etkileşim ve iletişim eksikliği olduğu varsayılabilir. Ayrıca, derslerin daha fazla uygulamaya yönelik olması ve staj süresi konularının vurgulanması; daha önce de belirtilen yeni mezunların uygulamaya yönelik faaliyet alanlarında yeterli bulunmadığı bulgusunu da desteklemektedir.

\subsection{Sektör beklentileri}

$\mathrm{Bu}$ bölümde katılımcı firmalardan ulusal düzeyde özel sektör beklentilerini karşılaması kapsamında; (i) yeni mezunların sahip olması gereken bilgi ve beceriler konusundaki düşünceleri ve (ii) mevcut durumu değerlendirmeleri istenmiştir.

Peyzaj mimarlığı lisans eğitiminin sektör beklentilerini karşılaması kapsamında yeni mezunların sahip olması gereken bilgi ve beceriler, faktör analizi sonucunda 5 grupta toplanmıştır. Bunlar sırasıyla; (i) doğal ve kültürel peyzaja ilişkin bilgi, (ii) peyzaj mimarlığı kuramı ve bitki bilgisi ile peyzaj planlama, tasarımı ve yönetimine ilişkin beceriler, (iii) mühendislik ve uygulama süreci bilgi ve becerileri, (iv) kişisel beceriler (sorumluluk alma gibi), (v) analitik düşünmeye yönelik beceriler ve yabanc1 dil bilgisidir. Frekans dağılımları incelendiğinde ise analitik düşünme becerisinin belirgin biçimde çok önemli $(\% 75)$ ve önemli (\%24) olarak değerlendirildiği görülmektedir (Şekil 4).

Bununla birlikte sorumluluk alma, yabanc1 dil bilgisi ve etik değerlere ilişkin bilgi ve beceriler gibi kişisel özelliklere ve gelişime bağlı konuların katılımcılar tarafından önemli bulunduğu anlaşılmaktadır. Mesleki bilgi anlamında ise mühendislik konularında bilgi ve beceriler; tasarım, planlama, bitki bilgisi ve yönetim konularına göre daha öncelikli öneme sahip olarak belirlenmiştir.

Firmaların faaliyet alanı ve ulusal düzeyde peyzaj mimarlığı sektör beklentilerini karşılaması kapsamında yeni mezunların sahip olması gereken bilgi ve beceriler arasında anlamlı bir ilişki olup olmadığının anlaşılması için uygulanan Ki-kare testi sonuçlarına göre, firma faaliyet alanı ile "süs bitkileri çoğaltma tekniklerine ilişkin bilgi ve beceriler" ve "bitki fizyolojisi bilgisi" arasında anlamlı bir ilişki saptanmıştır (sırasıyla $p=0.006 ; p=0.000$ ). Suralı regresyon analizi sonuçlarına göre; bitkisel üretim alanında faaliyet gösteren firmalar, çoklu alanda faaliyet gösteren firmalara göre süs bitkileri çoğaltma tekniğine ve bitki fizyolojisine verdiği önem (strasıyla 1/1.872=0.534; $1 / 1.281=0.780$ ) belirgin bir farkl1l1k göstermemekle birlikte; tasarım ve planlama alanlarında proje hizmeti veren firmalar özellikle bitki fizyolojisi konusundaki bilgiyi diğer firmalara göre belirgin bir biçimde (10 kat) daha az önemli bulmaktadır (Çizelge 5). Bu bulguya dayanarak eğitimde kazanılan bilgi ve becerilerin, farklı faaliyet alanlarına göre farklı önemlere sahip olabildikleri ileri sürülebilir.

Çizelge 4. Eğitimin yeterliliği konusunda katılımcıların değerlendirmeleri.

\begin{tabular}{|c|c|c|c|c|c|c|}
\hline Yeterlilik ifadeleri & $\begin{array}{l}\text { Çok } \\
\text { katıliyorum } \\
(\%) \\
\end{array}$ & $\begin{array}{l}\text { Katıliyorum } \\
\qquad \%)\end{array}$ & $\begin{array}{l}\text { Kararsizim } \\
\qquad \%)\end{array}$ & $\begin{array}{l}\text { Katılmiyorum } \\
\qquad \%)\end{array}$ & $\begin{array}{c}\text { Kesinlikle } \\
\text { katılmıyorum } \\
(\%)\end{array}$ & $\begin{array}{l}\text { Fikrim } \\
\text { yok }\end{array}$ \\
\hline $\begin{array}{l}\text { Mezun olan öğrencilerin aldıkları eğitimi özel sektörde } \\
\text { iş bulma açısından yeterli görüyorum. }\end{array}$ & 5 & 12 & 12 & 39 & 32 & - \\
\hline $\begin{array}{l}\text { Derslerin daha fazla uygulamalı olarak yürütülmesi } \\
\text { gerektiğine inanıyorum. }\end{array}$ & 68 & 31 & 1 & - & - & - \\
\hline Staj sürelerinin uzatılması gerektiğini düşünüyorum. & 46 & 39 & 8 & 7 & - & - \\
\hline $\begin{array}{l}\text { Mesleki bilginin yanı sıra kişisel gelişime ilişkin } \\
\text { çabaları gerekli görüyorum. }\end{array}$ & 61 & 32 & 5 & 1 & - & - \\
\hline $\begin{array}{l}\text { Lisansüstü eğitimin bilgi ve becerilerin gelişmesi için } \\
\text { gerekli olduğunu düşünüyorum. }\end{array}$ & 12 & 24 & 23 & 32 & 8 & 1 \\
\hline $\begin{array}{l}\text { Eğitimde görev alanların sektörle daha fazla işbirliği } \\
\text { içinde olmaları gerektiğini düşünüyorum. }\end{array}$ & 70 & 27 & 3 & - & - & - \\
\hline $\begin{array}{l}\text { Yeni mezunların ulusal ve uluslararası düzeyde yeni } \\
\text { arayışlara ve teknolojilere ilişsin bilgi ve fikir sahibi } \\
\text { olmasının gerekli olduğunu düşünüyorum. }\end{array}$ & 65 & 29 & 5 & - & 1 & - \\
\hline
\end{tabular}




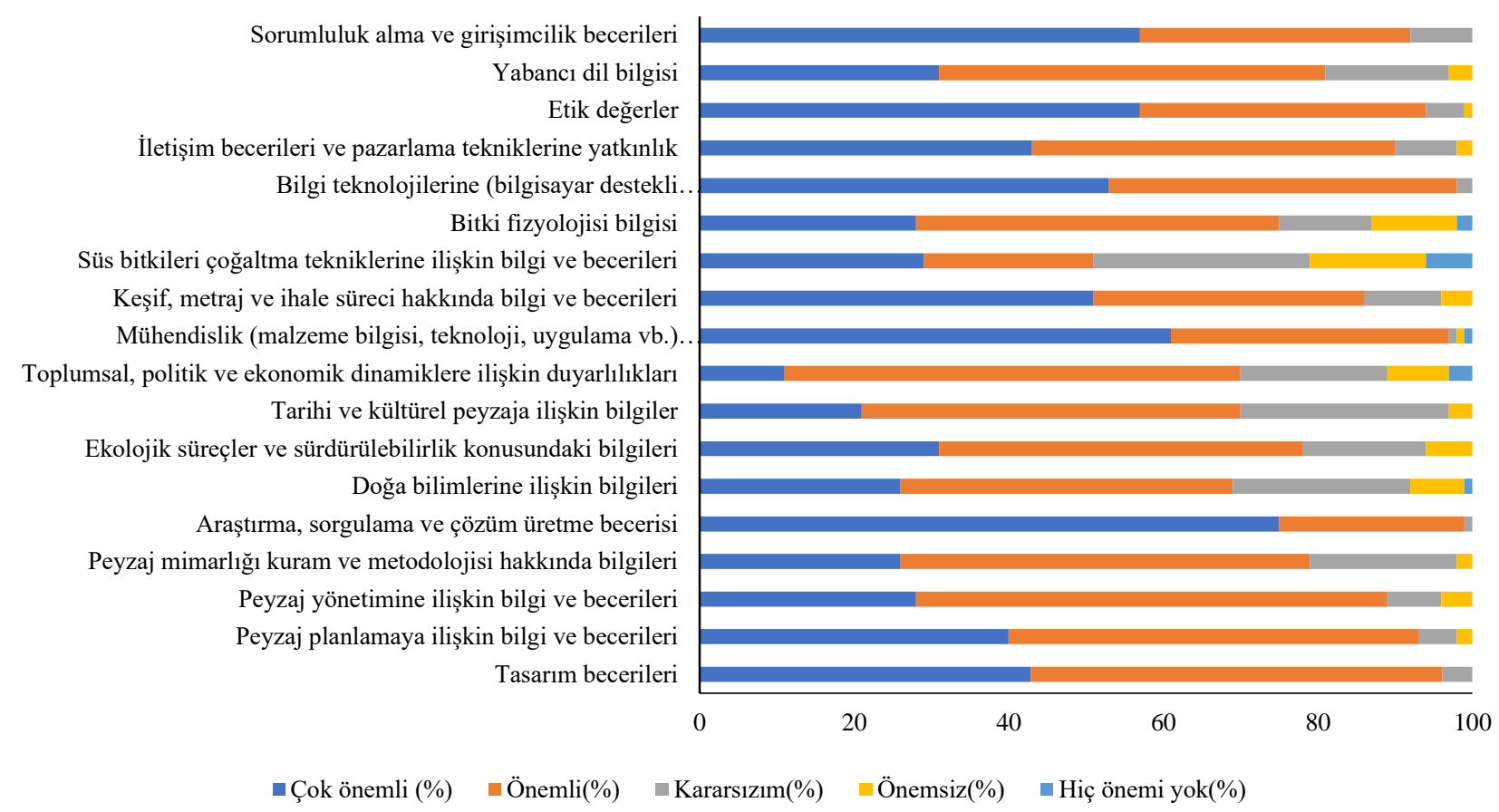

Şekil 4. Yeni mezunların sahip olması gereken bilgi ve beceriler konusundaki düşünceler

Çizelge 5. Firma faaliyet alanına göre süs bitkileri çoğaltma tekniğine ilişkin bilgi ve becerilerin önemi

\begin{tabular}{|c|c|c|c|c|}
\hline $\begin{array}{l}\text { Bağımlı değişken: Süs bitkileri çoğaltma tekniğine ilişkin bilgi ve becerilerin önemi } \\
\text { Bağımsız değişken: Firma faaliyet alanı }\end{array}$ & $\beta$ & Wald & OR $\left(e^{\beta}\right)$ & $\mathrm{p}$ \\
\hline Bitkisel üretim ve uygulama & -1.872 & 12.808 & 0.153816 & 0.000 \\
\hline Tasarım ve Planlama & 0.462 & 0.615 & 1.587245 & 0.0433 \\
\hline Çoklu faaliyet alanı & $0^{\mathrm{a}}$ & . & & . \\
\hline \multicolumn{5}{|l|}{$\begin{array}{l}\text { Bağımlı değişken: Bitki fizyolojisine ilişkin bilginin önemi } \\
\text { Bağımsız değişken: Firma faaliyet alanı }\end{array}$} \\
\hline Bitkisel üretim ve uygulama & -1.281 & 5.787 & 0.277759 & 0.016 \\
\hline Tasarım ve Planlama & 2.307 & 11.983 & 10.04425 & 0.001 \\
\hline Çoklu faaliyet alanı & $0^{\mathrm{a}}$ & . & & . \\
\hline
\end{tabular}

Yeni mezunların sahip olması gereken bilgi ve becerileri önem derecelerine göre değerlendirmelerinin ardından, katılımc1 firmalardan güncel durumu değerlendirmeleri istenmiş ve bu amaçla yeni mezun öğrencilerin bilgi ve beceri düzeyleri hakkındaki değerlendirmeleri almak üzere aynı konu başlıkları sunulmuştur. Bulgular, eğitim yeterliliği bölümünde belirtildiği üzere üniversitelerde verilen lisans eğitiminin özel sektörce yeterli bulunmadığı sonucunu desteklemektedir (Şekil 5). Özellikle mühendislik, keşif-metraj, süs bitkileri çoğaltma ve peyzaj planlama konularında yeni mezunlar özel sektör tarafindan yetersiz görülmektedir. Mühendislik alanında yeni mezunları yeterli ve çok yeterli olarak değerlendiren firmaların oranı yalnızca \%19 iken; peyzaj planlamaya ilişkin bilgi ve becerileri yeterli ve çok yeterli gören firmaların oranı is \%16'dır. Bu konular, daha önce belirtilen uygulamaya yönelik eğitimin yetersizliği bulgusu ile de doğrudan ilişkilidir. Benzer Şekilde peyzaj mimarlığı bölümü mezunları da kendilerini uygulama ve malzeme bilgisi konularında yetersiz görmektedirler (Gül vd.,2011).

Yeterlilik konusunda ise bilgi teknolojilerine ilişkin bilgi ve beceriler; $\% 51$ yeterli ve $\% 6$ çok yeterli olmak üzere değerlendirilmiştir. Bu bulgu Gül vd. (2011) tarafından gerçekleştirilen araştırmanın bulguları ile çelişmektedir. Araştırmada mezunların $\% 75$ ' $\mathrm{i}$ "bilgisayar destekli planlama, tasarım ve modelleme" konusunda verilen eğitimi yetersiz bulmuşlardır. İki araştırma arasında geçen 7 yıl içerisinde bu konuda eğitim yeterliliğinin artış gösterdiğini, artan öğrenci sayısı ve bölümlerin kısıtlı olanakları çerçevesinde varsaymak olanaklı gözükmemekle birlikte; bu iki çalışmanın hedef kitlelerinin eğitim yeterliliklerini farklı açılardan ve farklı ilkelerle değerlendirdikleri öne sürülebilir.

Son olarak katılımcılardan, işveren olarak peyzaj mimarlı̆̆ öğrencilere yönelik görüşlerini ve eleştirilerini yazmaları istenmiş; metin uzunluğuna ya da içeriğine herhangi bir kısıtlama getirilmemiştir. Bu soruyu katılımcıların yalnızca \%60'ı cevaplamıştır. Tüm metinler, dikkatlice okunarak katılımcilar tarafindan vurgu yapilan kavramlar belirlenmiștir. Birbiri ile ilișkili kavramlar dikkate alınarak bir sınıflandırma gerçekleştirilmiş; kavramların metinlerde tekrar ediş sıklıkları takip edilmiştir. Sonuç olarak görüşler ve eleştiriler 12 maddede toplanarak, tüm metinlerde tekrar edişlerine bağlı olarak hesaplanan frekans dağılımları ile birlikte Çizelge 6'da verilmiştir. Daha önceki bulguları destekleyecek biçimde, eğitimde uygulamaya yönelik faaliyetlerin arttırılması en çok ifade edilen görüş olmuştur. Yine, mühendislik ve staj konularına ilişkin olarak iyileștirmelerin ve zenginleștirmelerin talep edilmesi elde 
edilen bulgularla tutarlılık göstermektedir. Katılımcıların eğitim sisteminin yapılanmasına yönelik önerileri arasında en çok dikkat çekenleri ise bölümlerin yetenek sınavı ile ögrenci alması ve eğitimin 5 ya da 6 yıla çıkarılmasıdır. Özel sektörün, eğitim sektöründe çalışan peyzaj mimarlarına karşı en belirgin eleştirileri ise, eğitimcilerin meslek profesyonelleri ile ilişkide olmayıp; meslek pratiğinden habersiz oluşlarıdır. Peyzaj mimarlığı çalışma alanları kapsaminda en önemli konulardan biri olan insan ve toplum davranışını inceleyen sosyal bilim dallarında eğitimin yetersiz oluşu ise, az sayıda katılımcı firma tarafından dile getirilmiştir. Oysa kamusal açık alanlara sosyal değerlerin katılması, sosyal sürdürülebilirliğin desteklenmesi ve dezavantajlı gruplara kamusal alanda eşitlik getirecek çözümlerin üretilmesi IFLA/UNESCO Peyzaj Mimarlığ Eğitim Belgesi'nde eğitimin toplumların farklı ihtiyaçlarına cevap vermek üzere kurgulanan eğitim nitelikleri olarak vurgulanmaktadır (IFLA, 2012).
Sorumluluk alma ve girişimcilik becerileri
Yabancı dil bilgisi
Etik değerler

İletişim becerileri ve pazarlama tekniklerine yatkınlık
lojilerine (bilgisayar destekli tasarım/planlama/sunum)

Bilgi teknolojilerine (bilgisayar destekli tasarım/planlama/sunum)
Bitki fizyolojisi bilgisi

Süs bitkileri çoğaltma tekniklerine ilişkin bilgi ve becerileri

Keşif, metraj ve ihale süreci hakkında bilgi ve becerileri

Mühendislik (malzeme bilgisi, teknoloji, uygulama vb.)

Toplumsal, politik ve ekonomik dinamiklere ilişkin duyarlılıkları

Tarihi ve kültürel peyzaja ilişsin bilgiler

Ekolojik süreçler ve sürdürülebilirlik konusundaki bilgileri

Doğa bilimlerine ilişkin bilgileri

Araştırma, sorgulama ve çözüm üretme becerisi

Peyzaj mimarlığı kuram ve metodolojisi hakkında bilgileri

Peyzaj yönetimine ilişkin bilgi ve becerileri

Peyzaj planlamaya ilişkin bilgi ve becerileri

Tasarım becerileri

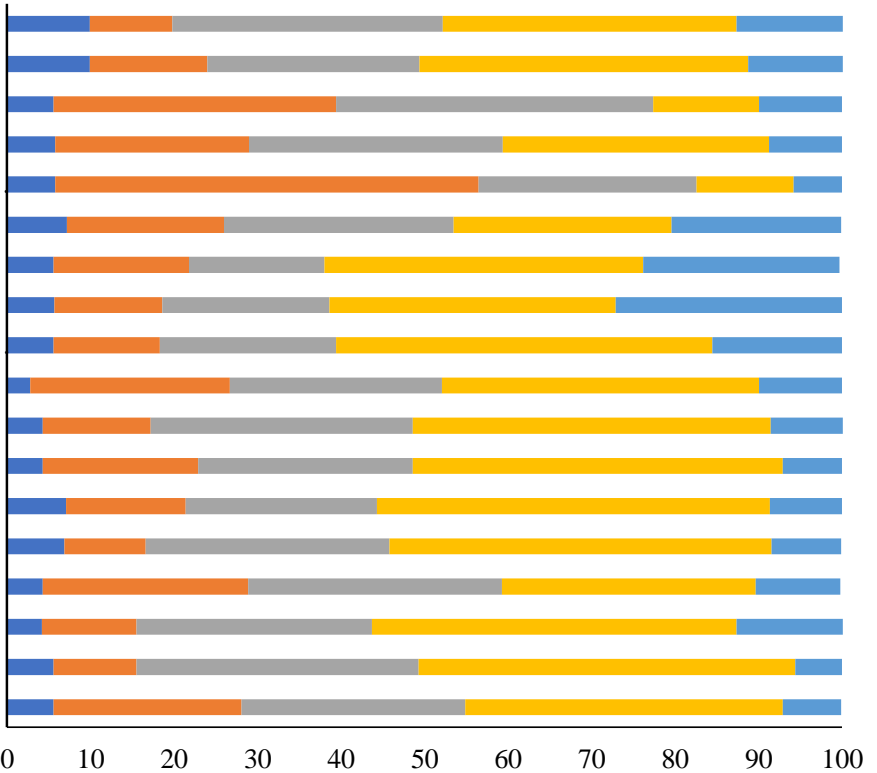

- Çok yeterli (\%)

Yeterli $(\%)$

Kararsızım(\%)

Yetersiz $(\%) \quad$ Cok yetersiz $(\%)$

Şekil 5. Yeni mezunların sahip oldukları bilgi ve beceri düzeyleri hakkındaki değerlendirmeler

Çizelge 6. Katılımcıların eğitime yönelik görüşleri ve eleştirileri

\begin{tabular}{|c|c|}
\hline Görüş ve eleştiriler & Frekans dağılımı (\%) \\
\hline Eğitimin uygulamaya yönelik olarak gerçekleştirilmesi. & $\% 20$ \\
\hline Malzeme ve mühendislik bilgisinin geliștirilmesi. & $\% 16$ \\
\hline Stajların daha uzun süreli ve/veya daha fazla sayıda gerçekleştirilmesi. & $\% 13$ \\
\hline Eğitimcilerin sektörle iletişimini koparmaması ve eğitim sürecinde meslek profesyonellerinden destek alınması. & $\% 13$ \\
\hline Öğrencilerin kişisel beceri ve yeteneklerini geliștirmeye yönelik çaba sarf etmesi. & $\% 10$ \\
\hline Lisans eğitiminin yeniden yapılandırılması gerekliliği. & $\% 6$ \\
\hline $\begin{array}{l}\text { Eğitim programlarında tasarıma daha fazla yer verilmesi, yaratıcılığın desteklenmesi ve tasarım ürünlerinde dil birliğinin } \\
\text { sağlanması. }\end{array}$ & $\% 6$ \\
\hline Keșif-metraj ve uygulama projesi hazırlama konusundaki yetersizlikler. & $\% 4$ \\
\hline Bilgisayar teknolojilerindeki gelişmelerin takip edilmesi ve görselleştirme teknolojisinin daha iyi kullanılması. & $\% 4$ \\
\hline Eğitim sektöründeki peyzaj mimarlarının, peyzaj mimarlı̆̆ı pratiği hakkında fikir sahibi olmaması. & $\% 3$ \\
\hline Mezunların mesleği benimsemiyor ve sahiplenmiyor olușu. & $\% 3$ \\
\hline İnsan psikolojisi ve sosyoloji konularının eğitimde yeterli seviyede verilmiyor oluşu. & $\% 1$ \\
\hline
\end{tabular}




\section{Tartışma ve sonuç}

$\mathrm{Bu}$ çalışma; peyzaj mimarlığı disiplini çalışma alanlarında faaliyet gösteren özel sektör firmalarının ulusal peyzaj mimarlığı lisans eğitimine bakışını ve mezunlardan, dolayısıyla eğitimden, beklentilerini belirlemek amacıyla gerçekleştirilmiştir. Çalışmanın en belirgin sonucu özel sektörün genel olarak verilen lisans eğitimini, özellikle uygulama açısından, yeterli bulmayışıdır. Öte yandan farklı fakülteler altında yapılanan; farklı konularda ve farklı oranlarda içeriklerle ders programlarının yürütüldüğü peyzaj mimarlığ 1 bölümlerinin, mevcut karmaşa içerisinde, farklı paydaşların beklentilerine ne kadar yanıt verilebileceği tartışma konusudur. Eğitim sektörü açısından en temel sorunlardan biri de, öğrenci sayısının her yıl artması; buna bağlı olarak üniversitelerde gerek personel gerekse fiziksel mekân koşullarının talebi karşılayamıyor olmasıdır.

Bununla birlikte peyzaj mimarlığı çalışma alanlarının çeşitlilik göstermesi de eğitimin kalitesini zorlayıcı unsurlardan bir diğeridir. Bulgularda verildiği üzere firmaların çoğu; tasarım, planlama, bitkisel üretim, uygulama konularından en az iki tanesi üzerine faaliyet göstermektedir. Bu konularının her birinin lisans eğitiminde, üstelik uygulamalı olarak, ele alınması için eğitim sisteminin yeniden yapılanması gerekmektedir. Bu anlamda eğitim süresinin, eğitimin ilk yıllarında olduğu gibi yeniden 5 yıla çıkarılması bir seçenek olarak değerlendirilebilir.

Bir başka tartışma konusu olan peyzaj mimarlığı bölümlerinin hangi fakülte altında yapılanması gerekliliği de, farklı faaliyet alanlarında eğitim kalitesinin iyileştirilmesi yönünden ele alınabilir. Her ne kadar mevcut eğilim peyzaj mimarlığı bölümlerinin mimarlık fakülteleri altında yapılanması yönündeyse de, farklı fakülteler altında verilen peyzaj mimarlığı eğitimi, farklı faaliyet alanlarında uzmanlaşmaya yönelik eğitim ve araştırma çeşitliliğinin artması açısından bir olanak olarak değerlendirilebilir. Ancak mevcut durumda, farklı konulardaki teorik ve uygulamalı ders yükü dağılımları ve akademik personelin araştırma alanları ile bölümlerin yer aldıkları fakültelerin öncelikli çalışma konuları her zaman örtüşmemektedir. Bu gibi durumlarda disiplinler arası etkileşim olanakları kısıtlanmakta; eğitim ve araştırma niteliği de olumsuz etkilenmektedir. Ayrıca farklı fakülteler altında peyzaj mimarlığı bölümlerinin yapılanması, mezunların özellikle kamuda istihdamı konusunda sorunlara neden olabilmektedir. Tüm peyzaj mimarlığı bölümleri mezunları, "peyzaj mimarı" unvanını almakta; ancak eğitim aldıkları programın içeriği ve kapsamı birbirinden farklılık göstermektedir. Bunun sonucunda YÖK Yürütme Kurulu'nun daha önce bahsedilen kararı gibi farklı gerekçelerle mezunların istihdam olanaklarının kısıtlanması söz konusudur.

Katılımcı firmalar tarafindan uygulamalı eğitimin desteklenmesine yönelik olarak ifade edilen staj süresinin uzatılması ve staj sayısının artırılması ile ilgili olarak iki temel konu söz konusudur: uzun dönemli ve çok sayıda stajyeri bünyesinde çalıştırabilecek nitelikli firma sayısı ve çeşitliliği ile stajyerlerin verimli olarak çalışmasının sağlanması. Öğrencilerin belirli bir deneyimi ve gerek fiziksel gerekse personel kapasitesi olan firmalarda staj sürelerini etkin geçirmeleri sağlanmalıdır. Bu nedenle staj yapılacak firmaya ilişkin ve staj süresince öğrencinin performansını ölçmeye ilişkin ilkeler ve prosedür tanımlı olmalıdır. Aksi takdirde staj süresinin uzun olması, bu süreçte yapılan işin niteliğini iyileştirmeyecektir.

Peyzaj mimarlığı eğitiminin desteklemede yetersiz kaldığı ifade edilen öğrencilerin analitik düşünme, inisiyatif alabilme, iletişim kurabilme gibi becerileri ise daha kolaylıkla çözümlenebilecek bir konudur. $\mathrm{Bu}$ konuda öğretim elemanlarının, özellikle uygulamalı derslerde öğrencinin aktif olarak yer aldığı öğretim metodolojilerini uygulaması faydalı olacaktır. Stüdyo eğitimleri ile, ölçme ve değerlendirme yöntemi olarak proje/ödev jürileri yoluyla öğrencinin kendini ifade etme, grup ve bireysel olarak çalışabilme, tartışmaya katılma, eleştirileri cevaplama gibi eylemlerde bulunması teşvik edilecektir. Ancak bu kapsamda, öğrenci sayısının fazla olması ve öğrenci başına düşen ögretim elemanı sayısının her zaman yeterli olmayışı yine temel sorunlar olarak ortaya çıkmaktadır. Konuyla ilgili olarak, 2 Kasım 2018'de yürürlüğe giren ve YÖK tarafından hazırlanan "Norm Kadro Yönetmeliği”" ile yeni açılan üniversitelerdeki peyzaj mimarlığı bölümlerine kısa vadede öğretim elemanı kadrosu temini kolaylaşmış olmakla birlikte, eğitim veren bölüm sayısındaki artışın eğitimin niteliği üzerindeki etkileri de ayrıca irdelenmesi gereken bir konudur (Anonim, 2018d).

$\mathrm{Bu}$ çalışmada önemli bulunan konulardan biri de eğitim sektöründe yer alan öğretim elemanlarının, meslek profesyonelleri ve pratiği ile ilişkilerinin zayıf olduğu yönündeki değerlendirmelerdir. Kuram, bilgi ve uygulama arasında bir denge kurulmasının her iki taraf için faydalı olacağı açıktır. Malzeme ve uygulama teknolojisinin çok hızlı geliştiği bu dönemde, meslek profesyonellerinin eğitim programları içerisinde etkinliklere dahil edilmesinin hem öğrencinin hem de akademik personelin meslek pratiğinde günceli yakalamasında faydalı olacağı düşünülmektedir. Aynı zamanda pratikte proje ve uygulama süreçlerinin nasıl işlediği, temel sorunların neler olduğu ve mevzuatın peyzaj mimarlığı faaliyetleri üzerindeki etkisi konularında özel sektörün deneyimlerinin paylaşılması önemlidir. Ayrıca, meslek disiplininin sorunlarına ilişkin çözümlerin geliştirilmesinde her iki paydaşın da aynı sorumluluğa sahip olduğu ve ortak hareket etmenin peyzaj mimarlığı disiplinini güçlendireceği unutulmamalıdır.

Son olarak, bulgu ve değerlendirmelerin daha sonraki araştırmalarda kullanımının etkinliği açısından çalışmanın kısıtlarını ortaya koymak gerekmektedir. $\mathrm{Bu}$ çalışmada karşılaşılan en temel sorun, özel sektörde peyzaj mimarlığı çalışma alanlarında faaliyet gösteren firma sayısını ve iletişim bilgilerini temin etmek olmuştur. Bu konuda gerek TMMOB PMO gerekse eğitim kurumlarının veri tabanları yetersizdir. Meslek odası verileri ise ilk kayıt verisinde dayanmaktadır; güncel değildir. Ayrıca tüm firmalar meslek odasına kayıtlı değildir. Dolayısıyla örneklem sayısının belirlenebileceği evrene ait bir veri bulunmamaktadır. Mezun sayıları bile tahmini olarak hesaplanabilmektedir. IFLA tarafından eğitimin akreditasyonu için gerekli olan mezun veri tabanlarının da bölümler tarafından ivedilikle oluşturulması gerekmektedir. Veri olmadan paydaşlara yönelik değerlendirmelerin yapılmasının ve eğitim sektörü olarak disiplinin diğer paydaşlarından bağımsız bir yol izlemenin mesleğin gelişimi açısından yararlı olmayacağı düşünülmektedir. 


\section{Kaynaklar}

Anonim, 2017. İTÜ Peyzaj mimarlığı bölümümüzde uluslararası akreditasyon. İstanbul Teknik Üniversitesi, İstanbul, http://www.itu.edu.tr/haberler/2017/05/11/pey zaj-mimarligi-bolumumuze-uluslararasi-akreditasyon, Erişim: 27.11.2018.

Anonim, 2018a. İstanbul Teknik Üniversitesi öğrenci işleri daire başkanlığı peyzaj mimarlığı lisans ders planı. İstanbul Teknik Üniversitesi, İstanbul, http://www.sis.itu.edu.tr/tr/dersplan/plan/PEM/000000.h tml, Erişim: 18.11.2018.

Anonim, 2018b. İstanbul Üniversitesi eğitim bilgi sistemi peyzaj mimarlığı lisans ders programı. İstanbul Üniversitesi, İstanbul, http://ebs.istanbul.edu.tr/ home/dersprogram/?id=1135\&yil=2016, Erişim: 18.11.2018.

Anonim, 2018c. Ankara Üniversitesi bologna bilgi sistemi peyzaj mimarlığ 1 lisans ders programı ve AKTS kredileri. Ankara Üniversitesi, Ankara, http:// bbs.ankara.edu.tr/Ders_Plani.aspx?bno=1830\&bot=427, Erişim: 18.11.2018.

Anonim, 2018d. Devlet yükseköğretim kurumlarında öğretim elemanı norm kadrolarının belirlenmesine ve kullanılmasına ilişkin yönetmelik. Mevzuat Bilgi Sistemi, Ankara, http://www.mevzuat.gov.tr/ MevzuatMetin/3.5.20146459.pdf., Erişim: 03.11.2018.

Bruns, D., Ortaçeşme, V., Stiles, R., de Vries, J., Holden, R., Jorgensen, K., 2010. ECLAS Guidance on landscape architecture education. The Tuning Project ECLAS LE:NOTRE. Tuning Landscape Architecture Education in Europe, Report, Version 26. European Council of Landscape Architecture Schools, http://www.unideusto .org/tuningeu/images/stories/Summary_of_outcomes_T N/ECLAS_Guidance_on_Landscape_Architecture_Edu cation.pdf, Erişim: 11.11.2018.

Fetzer, E., 2014. Knowledge Building in Landscape Architecture. Kassel University Press, Kassel.
Gazvoda, D., 2002. Characteristics of modern landscape architecture and its education. Landscape and Urban Planning, 60: 117-133.

Gül, A., Örücü, Ö.K., Eraslan, Ş., 2011. Mezun peyzaj mimarlarının eğitim ve öğretimden beklentileri. SDÜ Orman Fakültesi Dergisi, 12: 131-140.

IFLA, 2012. IFLA/UNESCO charter for landscape architectural education, http://iflaonline.org/wp-content/ uploads/2014/11/IFLA-Charter-for-LandscapeArchitectural-Education-Revised-2012.pdf, Erişim: 12.01.2017.

Kaplan, A., 2009. Landscape architecture's commitment to landscape concept: a missing link?. Journal of Landscape Architecture, 4(1): 56-65.

ÖSYM, 2017. Merkezi yerleştirme ile öğrenci alan yükseköğretim lisans programları. Öğrenci Seçme ve Yerleştirme Merkezi, Ankara, https://dokuman. osym.gov.tr/pdfdokuman/2017/OSYS/YER/Tablo4_12082017.pdf, Erişim: 24.11.2018.

ÖSYM, 2018a. Merkezi yerleştirme ile öğrenci alan yükseköğretim lisans programları. Öğrenci Seçme ve Yerleştirme Merkezi, Ankara, https://dokuman. osym.gov.tr/pdfdokuman/2018/YKS/YER/Tablo4MinM ax_31082018.pdf, Erişim: 24.11.2018.

ÖSYM, 2018b. Ek yerleştirme ile öğrenci alan yükseköğretim lisans programları. Öğrenci Seçme ve Yerleştirme Merkezi, Ankara, https://dokuman. osym.gov.tr/pdfdokuman/2018/YKS/EK/TABLO4_28092018.pdf, Erişim: 24.11.2018.

PEMKON, 2018. PEMKON kararları. Peyzaj Mimarlığı Eğitim ve Bilim Derneği, Antalya, http://pemder.org.tr/ kararlar/, Erişim: 29.11.2018

PMO, 2018. Yükseköğretim Kurulu Başkanlığı̀nın kararına karşı dava süreci başlatıldı. Peyzaj Mimarları Odası, Ankara, http://www.peyzaj.org.tr/genel/bizden_detay. php?kod=7847\&tipi=1\&sube=0., Erişim: 28.11.2018. 